\title{
Fractionation of nitrogen compounds and carbohydrates in forages of different ages ${ }^{1}$
}

\section{Fracionamento de compostos nitrogenados e carboidratos em forragens de diferentes idades}

\author{
Alexandre Paula Braga ${ }^{2}$; Liz Carolina da Silva Lagos Cortes Assis ${ }^{2}$; Jesane Alves \\ de Lucena²; Jailma Suerda Silva de Lima ${ }^{3}$; Tatiana Fernanda Barbosa Barreto ${ }^{4 *}$; \\ Antônia Vilma de Andrade Ferreira Amâncio ${ }^{4}$; Francyelle Gurgel de Castro Alves \\ Genildo Fonseca Pereira ${ }^{5}$
}

\begin{abstract}
The objective of this study was to evaluate the chemical composition and protein and carbohydrate fractions in three forage species (Andropogon gayanus Kunth, Cenchrus ciliares L. and Panicum maximun x Panicum infestum) at four cutting ages: 21, 35, 49 and 63 days. Experiments were carried out at the Federal Institute of Education Science and Technology of Rio Grande do Norte - IFRN, located in the municipality of Apodi- RN, Potiguar West Meso-region. Materials collected in the field were analyzed in the Laboratory of Animal Nutrition (LANA), Federal Rural Semiarid University (UFERSA), Campus Mossoró, RN. Samples were processed, phenated, and analyzed. The analysis conducted included fractionation of nitrogen compounds and carbohydrates and chemical composition (dry matter, mineral matter, crude protein, lipids and fibers) was determined. The forages evaluated showed decreasing crude protein content with increasing cutting age, ranging between 14.9 and $6.2 \%$. Andropogon grass showed the highest crude protein content. The fiber content increased with age. Fiber consisted of $62.4 \%-70.0 \%$ NDF and $30.07 \%-33.03 \%$ ADF. Highest fiber content was recorded for Massai grass, in which case, these two component species showed the highest fractions of intermediate degradation protein (B2), while Andropogon and Buffel Capins showed higher fractions of non-fibrous carbohydrates (A and B1). An increase in the concentration of cell-wall material in the detriment of the cellular content with increasing plant age was observed in the fodder studied. We also observed an increase in the indigestible fraction (C) of proteins and carbohydrates in the species studied.
\end{abstract}

Key words: Cutting age. Fiber. Forage. Hay.

\section{Resumo}

Objetivou-se avaliar a composição química e os fracionamentos protéicos e de carboidratos em três espécies forrageiras (Andropogon gayanus Kunth, Cenchrus ciliares L. e Panicum maximun x Panicum infestum) em quatro idades de corte: $21,35,49$ e 63 dias. O procedimento experimental foi realizado

1 Parte da Dissertação de Mestrado do Programa de Pós-Graduação em Produção animal do segundo autor.

2 Profs., Curso de Pós-Graduação em Produção Animal, Universidade Federal do Rio Grande do Norte, Universidade Federal Rural do Semi-Árido, UFRN/UFERSA, Mossoró, RN, Brasil. E-mail: apbraga@ufersa.edu.br; Jesane@ufersa.edu.br; liz@ ufersa.edu.br

3 Prof., UFERSA, Mossoró, RN, Brasil. E-mail: jailma@ufersa.edu.br

4 Discentes, UFRN/UFERSA, Mossoró, RN, Brasil. E-mail: tatianafernanda@ufersa.edu.br; vilmaamancio@ufersa.edu.br; francyelle.gurgel@ufersa.edu.br

5 Prof., IFRN, Instituto Federal de Educação, Ciência e Tecnologia do Rio Grande Do Norte, Mossoró, RN, Brasil. E-mail: genildo.pereira@ifrn.edu.br

Author for correspondence 
no Instituto Federal de Educação Ciência e Tecnologia do Rio Grande do Norte - IFRN, localizado no município de Apodi- RN, Mesorregião Oeste Potiguar. O material coletado no campo foi analisado no Laboratório de Nutrição Animal (LANA), da Universidade Federal Rural do Semiárido (UFERSA), Campus Mossoró, RN. As amostras foram processadas e fenadas e posteriormente analisadas. As análises realizadas foram: fracionamento de compostos nitrogenados e de carboidratos e a composição química (Matéria seca, matéria mineral, proteína bruta, lipídeos e fibras). As forrageiras apresentaram teor de proteína bruta decrescentes com o aumento da idade de corte, variando entre 14,9 e 6,2\%. O capim Andropogon apresentou o maior teor de proteína bruta. $\mathrm{O}$ teor de fibra aumentou com o avanço da idade, correspondendo de 62,4 a 70,0\% de FDN e 30,07 a 33,03\% de FDA; sendo observado o maior teor no capim Massai, onde estas duas espécies apresentaram as maiores frações de proteína de degradação intermediária (B2); e Os Capins Andropogon e o Buffel apresentaram maiores frações de carboidratos não fibrosos (A e B1). O aumento da concentração de parede celular em detrimento ao conteúdo celular com o avanço da maturidade das plantas, foi evidente nas forrageiras estudadas. Observando-se também o aumento na fração indigestível (C) de proteínas e carboidratos nas espécies.

Palavras-chave: Feno. Fibra. Forrageira. Idade de corte.

\section{Introduction}

The Brazilian Northeast region is characterized by adverse climatic conditions, such as high temperatures and scarce rainfall, which severely limit agricultural activities; this in turn results in nutritional deficiencies which compromise animal production. Thus, overall the region is one of low productivity, due to poor diet. The provision of good quality, low-cost, regular-supply food protein that can meet the requirements of ruminants is a recurrent problem.

A strategy used to improve semi-arid animal production in areas characterized by low productivity levels is adequate food management, especially during the dry seasons of the year. In this way, foods of high nutritional value and low cost become necessary. Therefore, there is a strong need to investigate the feasibility of including several alternative food sources and observe animal responses in productive and economic terms (LOUSADA JÚNIOR et al., 2006).

According to MOREIRA (2013), the systems of ruminant production in the Brazilian semi-arid regions of the Northeast are characterized by the predominance of extensive cattle rising based on the Caatinga flora as main source of bulk. However, the production of the native pastures of the Caatinga is limited, due to the marked regional seasonality, which makes the productive system vulnerable throughout the year.

In the last decades, there has been a significant evolution in the livestock production activity in the Northeast, mainly in relation to increasing the availability of forage with techniques to manipulate vegetation. Among the techniques used, the enrichment of the Caatinga resources has been highlighted, as it consists in the introduction of forages adapted to such climatic conditions in order to improve the quantity and quality of the fodder offered to the animals. Therefore, the objective of this study was to evaluate the chemical composition and fractionation of nitrogen compounds and carbohydrates of three different grasses at four cutting ages.

\section{Materials and Methods}

Planting and collection of the experimental materials was carried out at the Federal Institute of Science and Technology Education of Rio Grande do Norte - IFRN, located in the municipality of Apodi- RN, west of Potiguar mesoregion, located at $5^{\circ} 39^{\prime} 51^{\prime \prime} \mathrm{S}, 37^{\circ} 47^{\prime} 56^{\prime} \mathrm{W}$. The climate of the region is classed as BSh'W, according to the classification by Köppen (NIMER, 1989). The mean, minimum and maximum temperatures during the experimental period were 21, 29 and 37 
${ }^{\circ} \mathrm{C}$, respectively.Andropogon grass (Andropogon gayanus Kunth, cultivar cv. Planaltina) the Buffel grass (Cenchrus ciliares, cv. Grass) and the Massai grass (Panicum maximum x Panicum infestum, cv. Massai) were cultivated under irrigation. Samples were collected by the direct method, which consists of the removal of the entire forage layer available in an area of $1 \mathrm{~m}^{2}$ at a height of $20 \mathrm{~cm}$ from the soil surface. The cultivated area of each experimental plot consisted in $25 \mathrm{~m}^{2}$. Each cultivar was sampled at four different ages and each cutting age was replicated thrice. The evaluated cutting ages were $21,35,49$ and 63 days of regrowth.

The material collected in the field was analyzed from March through December 2016 at the Animal Nutrition Laboratory (LANA) of the Federal Rural Semiarid University (UFERSA), Campus Mossoró, $\mathrm{RN}$, located at $5^{\circ} 11^{\prime} 17^{\prime \prime} \mathrm{S}, 37^{\circ} 20^{\prime} 39^{\prime}$ W. All samples were pre-dried in a forced-air circulation oven at $65{ }^{\circ} \mathrm{C}$ for 72 hours. After drying, samples were milled in a Wiley mill with a $1 \mathrm{~mm}$ sieve screen prior to packing in appropriately labeled plastic pots.

The gravimetric technique was used for determination of dry matter (DM), with two phases: pre-drying, followed by final drying in an oven at $105^{\circ} \mathrm{C}$ for 4 hours, with weighing every 1 hour until constant weight. Determination of mineral matter was also carried out by the gravimetric method, using a muffle furnace at $550{ }^{\circ} \mathrm{C}$ for 5 hours for calcination of the samples, followed by weighing (SILVA; QUEIROZ, 2002).

The levels of acid detergent fiber (ADF) and neutral detergent fiber (NDF) were performed, according to the method proposed by Van Soest (1994). Crude protein (CP) and ethereal extract (EE) were determined by the Kjeldahl and Soxhlet methods, respectively. All analyzes were performed according to the methodology described by Silva and Queiroz (2002).

Fractionation of nitrogen compounds was performed according to the method of Cornell
(The Cornell Net Carbohydrate and Protein System (CNCPS). Protein fraction A was determined after treatment of the samples with $10 \%$ trichloroacetic acid (TCA), as reported by Licitra et al. (1996). Fraction A was obtained by treating the sample with $50 \mathrm{~mL}$ of distilled water for 30 minutes and then adding $10 \mathrm{~mL}$ of $10 \%$ tricloacetic acid for another 30 minutes. Residual nitrogen was determined by the difference between total and residual nitrogen.

Fraction B1 was evaluated after treatment of the sample with borate-phosphate buffer, according to Licitra et al. (1996). Briefly, the soluble nitrogen was obtained by incubating the sample in $50 \mathrm{~mL}$ of borate-phosphate buffer and $1 \mathrm{~mL}$ of sodium azide solution (1\%). After 3 hours, the sample was filtered through filter paper and residual nitrogen was determined. Total soluble nitrogen was calculated as the difference between total nitrogen and residual nitrogen treated in borate-phosphate buffer.

Fraction B3 was obtained from the difference between contents in neutral detergent insoluble nitrogen (NDIN) and acid detergent insoluble nitrogen (ADIN), while true protein, fraction $\mathrm{B} 2$, was calculated as the difference between fraction $\mathrm{B} 1$ and NDIN. Fraction $\mathrm{C}$ was considered as the content in ADIN.

Prior to carbohydrate fractionation, percentage of total carbohydrates (TC) was obtained using the equation proposed by Sniffen et al. (1992): TC = $100-(\% \mathrm{CP}+\% \mathrm{EE}+\% \mathrm{MM})$, where $\mathrm{CP}=$ crude protein; $\mathrm{EE}=$ ethereal extract and $\mathrm{MM}=$ mineral matter. Fibrous carbohydrates (FC or fraction B2) were obtained from the corrected NDF for ashes and protein (NDFcp); non-fibrous carbohydrates (NFC), or fractions with high ruminal degradation rates (A + B1) were calculated using the equation: 100 - (C+ B2). (SNIFFEN et al., 1992); where fraction A was determined by the anthrone technique described by Yemn and Willis (1954), while B1, was obtained by the equation: $\mathrm{B} 1=100-(\mathrm{C}+\mathrm{B} 2)$, after obtaining fraction $\mathrm{A}$ and fraction $\mathrm{C}$ by the lignin method "Sulfuric acid - Lignin Klason", multiplying lignin 
values by 2.4, according to Sniffen et al. (1992).

The experiment was laid in a randomized blocks design in split plots, with grass species (Andropogon, Buffel and Massai) in the main plot, and cutting ages $(21,35,49$ and 63 days) in the subplots. Means were compared using Tukey's test and polynomial regression analysis was performed on cutting ages, all at a significance $\mathrm{p}<0,05$.

\section{Results and Discussion}

Protein fractionation comprised analyzes of fractions A, B1, B2, B3, and C, which are described as follows:

There was a significant interaction $(\mathrm{p}<0.05)$ between species and cutting age for fraction A. This fraction is composed of non-protein nitrogen (NPN), which has a high ruminal degradation rate and usually tends to decline with forage age. Figure 1 shows the values found for fraction $A$ in the species under study, at the cutting ages sampled (, 21, 35, 49 and 63 days). Similar values were found by Sá et al. (2010) while analyzing the fractionation of nitrogen compounds in tropical grasses at different cutting ages, varying about $28.4,19.51$ and 16.49 , for ages of 28, 35 and 54 days, respectively. According to Russell et al. (1992) and Sá et al. (2010), NPN sources are necessary for adequate ruminal functioning, because ruminal microorganisms, which are fermenters of structural carbohydrates, use ammonia as a source of nitrogen. However, high concentrations of NPN can lead to losses of nitrogen if readily available carbon skeletons for microbial protein synthesis are insufficient. The Buffel and the Massai grass species showed the highest values for fraction $\mathrm{A}$; this would make these forages the more apt for best ruminal performance. Nevertheless, attention should be paid in relation to nitrogen supplementation in this case, so that a tight coupling between carbohydrates and proteins in the rumen is ensured for optimal results.

The other fraction with a high ruminal degradation rate, fraction $\mathrm{B} 1$, did not display a significant interaction $(p<0.05)$ between species and age. (Figure 2). The values for B1 decreased with increasing cutting age. Overall, they were considered low values, but typical of tropical grasses. According to Balsalobre et al. (2003), fraction B1 is of little importance in forage grasses, since it normally represents values lower than $10 \%$ of the total crude protein content.

Fraction B2, which has an intermediate rate of ruminal degradation, showed a significant interaction $(p<0.05)$ between species and cutting age. Increasing age reduced the levels of fraction B2 to a different extent in each grass species under study. Velásquez et al. (2010), analyzed the fractionation of nitrogen compounds in tropical grasses at different cutting ages. They found values for fraction B2 that approached those of the Buffel species, ranging from $23.77 \%$ to $31.84 \%$ at ages 28, 35 and 42 days. As for species Andropogon and Massai, similar values were found by Sá et al. (2010), when analyzing the fractionation of nitrogen compounds in tropical grasses at different cutting ages: $36.7 \%, 28.9 \%$ and $25.1 \%$, at ages 28 , 35 and 54 days, respectively. The Andropogon and the Massai grasses showed the highest values for fractions of intermediate degradation protein (B2), which may constitute a good contribution to the ruminal degradability, as well as a better nutritional quality of these forages. These differences may be related to the grass genotype of the species under study and to environmental conditions since, according to Gonçalves (2001), climate factors affect development and quality of forage plants, (Figure 3). 
Figure 1. Cutting age effect on the content of protein Figure 2. Cutting age effect on the content of fraction A in Andropogon, Buffel and Massai grass species.

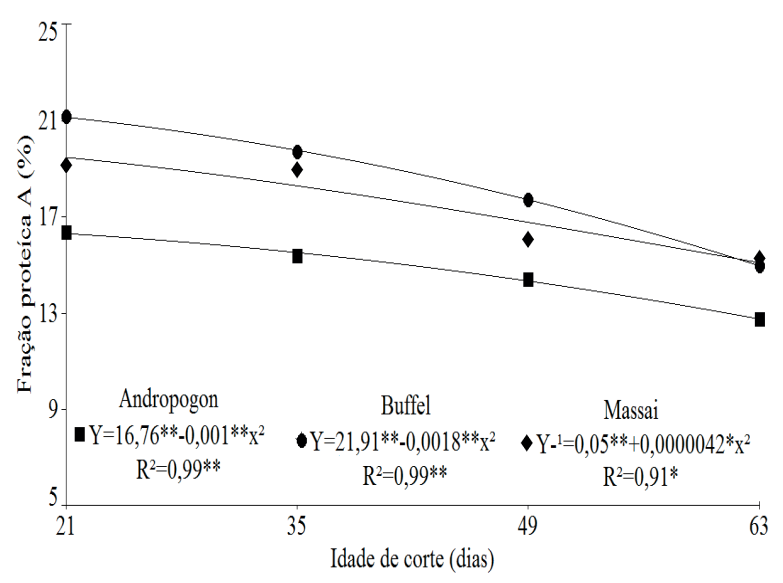
protein fraction B1 in Andropogon, Buffel and Massai grass species.

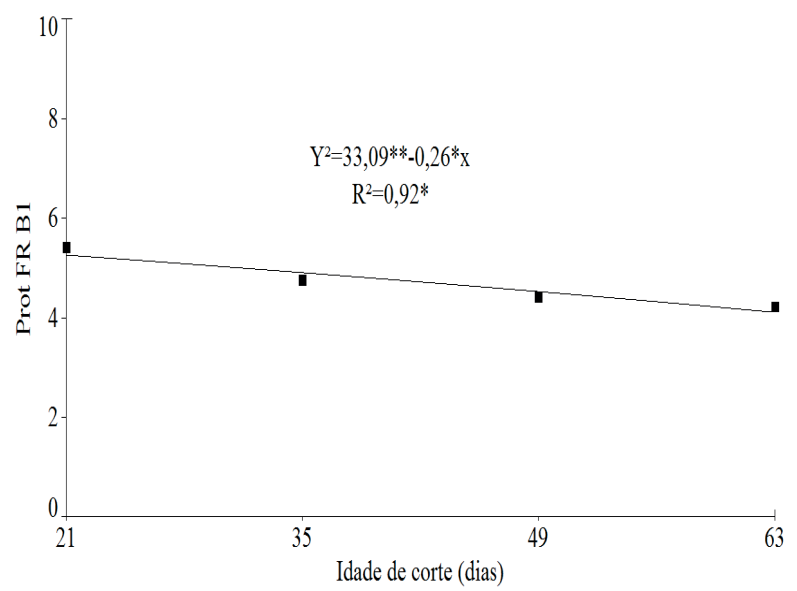

Fraction B3, which has a slow rate of ruminal degradation, showed a significant interaction $(p$ $<0.05$ ) between species and age, (Figure 4). Buffel grass showed the highest levels of fraction B3, which probably resulted from greater flowering of

this species during the experiment. Andropogon and Massai grasses, displayed an intermediate and lowest value, respectively, which is probably explained by a higher proportion of leaves observed in this last species, during the experiment.

Figure 3. Cutting age effect on the content of protein fraction B2 in Andropogon, Buffel and Massai grass species.

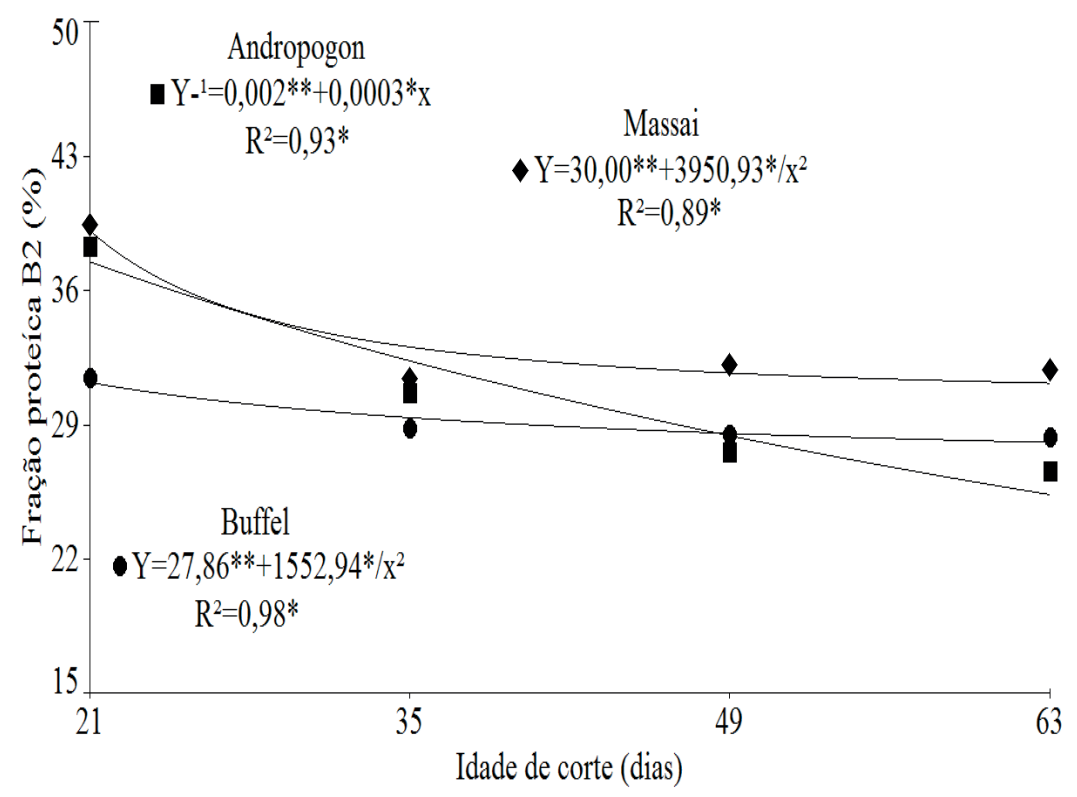


Figure 4. Cutting age effect on the content of protein fraction B3 in Andropogon Buffel and Massai grass species.

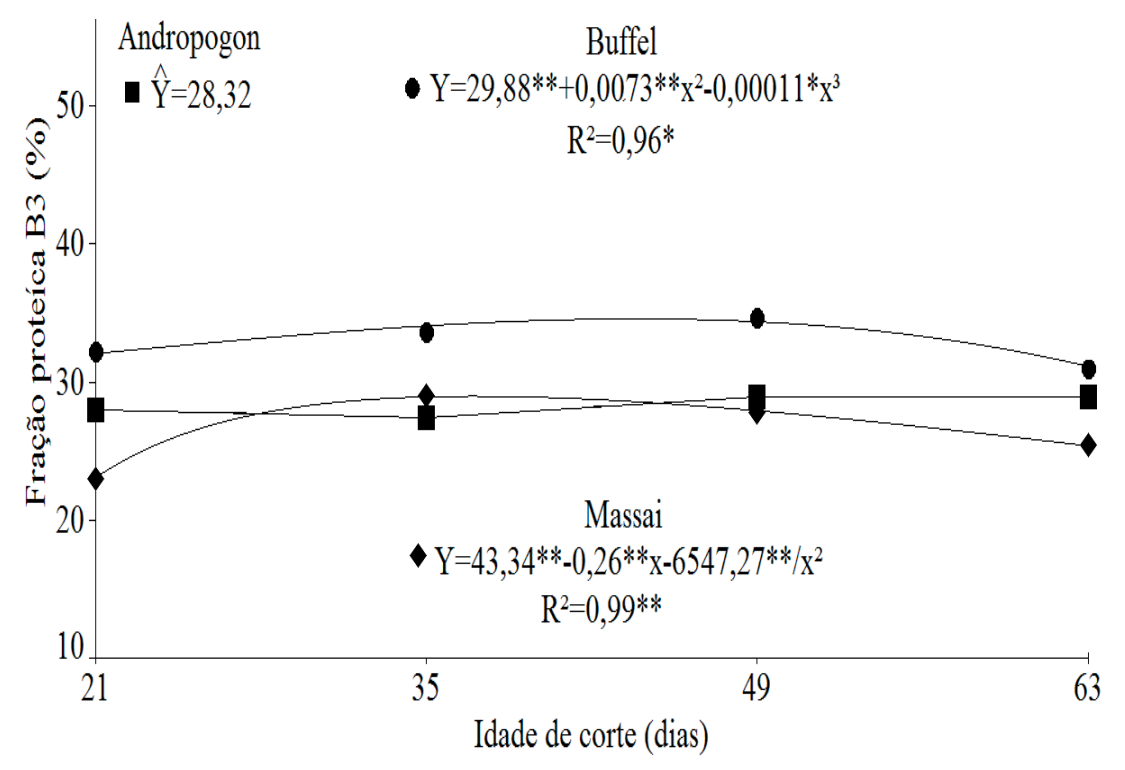

The slow degradation fraction (B3), increased with age. This fraction consists of proteins bound to the cell wall and are subjected to a slow rate of degradation, as they are digested mainly in the intestines (SÁ et al., 2010). In the Andropogon species, after decreasing from the first to the second age sampled, the value for fraction B3 increased over the last two age samplings. In the case of Buffel grass, there was a linear increase up to the third age, followed by a reduction at the last age sampling. In contrast, the Massai grass showed a great increase in B3 between ages 21 and 35 days, followed by a small decrease between ages 49 and 63 days. (Figure 4).

The proportion of insoluble non-digestible protein in the rumen and intestine (fraction C), presented a linear behavior, with values that varied from $11.12 \%$ to $27.26 \%$ in Andropogon grass; from $10: 45 \%$ to $21.32 \%$ in Buffel grass and from $11.60 \%$ to $21.74 \%$ in the Massai grass, for cutting ages 21 and 63 days, respectively. This fraction also showed a significant interaction $(\mathrm{p}<0.05)$ between species and age. We observed that fraction $\mathrm{C}$, an indigestible part present in the plant, increased with increasing cutting age (Figure 5), due to the presence of nitrogen attached to the lignin present in the stems. As to the lignin content, it was more abundant in the grass of Andropogon, which showed thick stems during the experiment. With increase in plant age, there was a decrease in leaf to stem ratio and an increase in lignin content, as usually observed in stems of tropical forages, which are characterized by a higher content of lignified material (VAN SOEST, 1994). 
Figure 5. Cutting age effect on the content of protein fraction $\mathrm{C}$ in Andropogon, Buffel and Massai grass species.

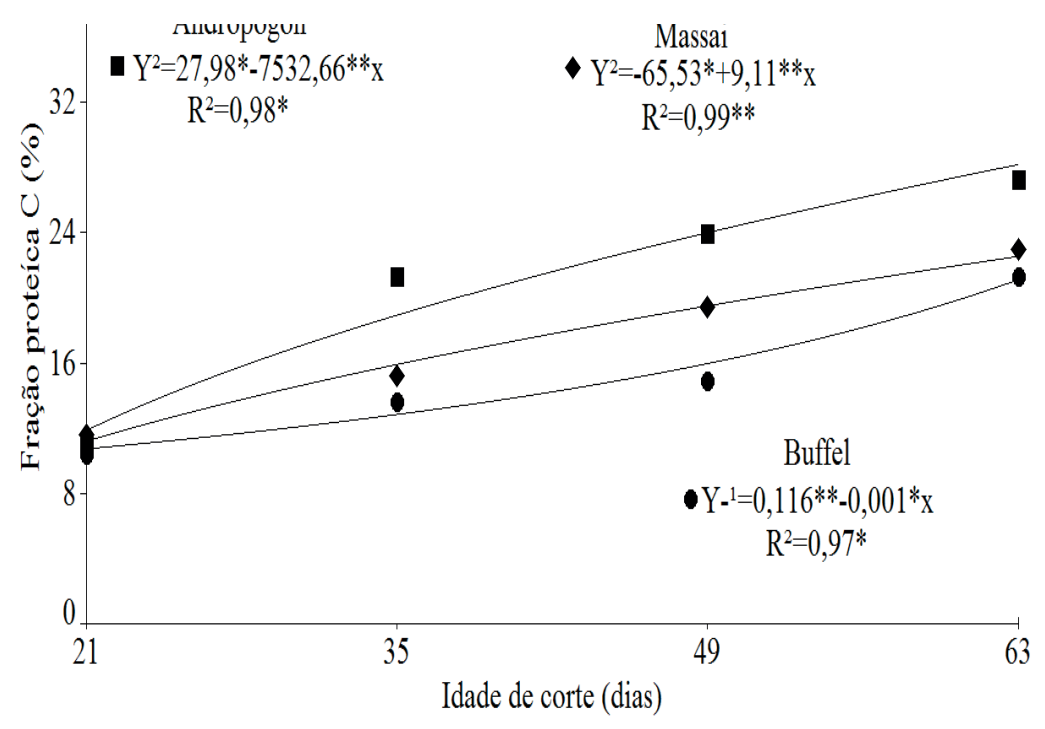

The fractionation of carbohydrates comprised analysis of fractions: A, B1, B2 and C. We found a significant interaction between species and age $(\mathrm{p}<$ 0.05 ) for all fractions, as described below.

Fraction A content values decreased with increasing cutting age. This decrease can be explained, not only by age at the time cutting, but also by the effect of temperature. According to Van Soest (1994) and Gonçalves (2001), high temperatures $\left(36.81{ }^{\circ} \mathrm{C}\right)$ caused accelerated metabolism in the plant, which rapidly used up cellular contents, while photosynthetic products were rapidly converted into structural components, (Figure 6). Velásquez et al. (2010), studying protein fractionation of different forages at ages 28,35 and 42 days documented values between $19.88 \%$ and $13.34 \%$ for this fraction.
In relation to fraction B1, Andropogon and Buffel grasses showed the greatest decrease in content of this fraction between ages 21 and 63 days, while in the Massai species there was a reduction in B1 values, between ages 35 and 49 days.

Carbohydrates of rapid rumen degradation, B1, showed decreasing values in all grasses tested, with increasing age, (Figure 7), but in different proportions each -as expected, since the structural components of the cell wall increase at the expense of non-fibrous carbohydrates as the plant develops (VAN SOEST, 1994; SÁ et al., 2010). Higher values of B1 were observed for Andropogon and Buffel grasses. The lower levels of fraction B1 are justified in the case of the Massai grass, because the values of NDF were relatively higher in relation to the other two species. 
Figure 6. Cutting age effect on the content of carbohydrate fraction A in Andropogon, Buffel and Massai grass species.

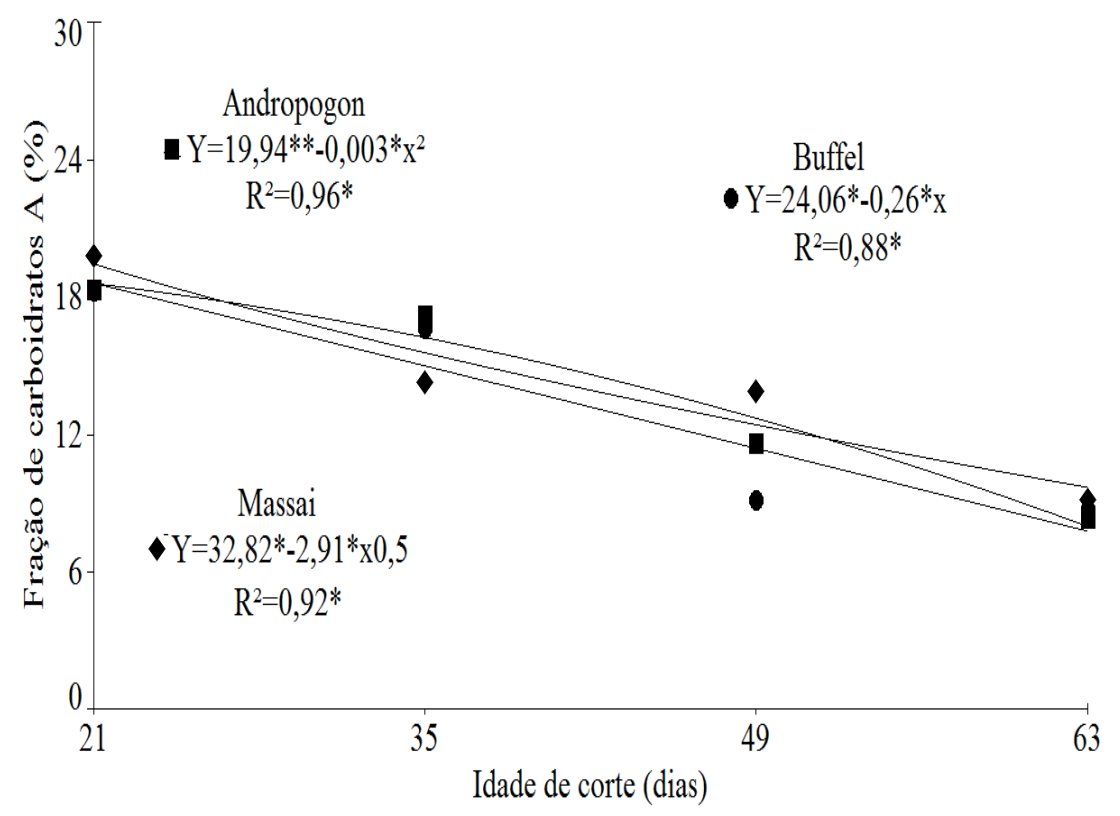

Figure 7. Cutting age effect on the content of carbohydrate fraction B1 in Andropogon, Buffel and Massai grass species.

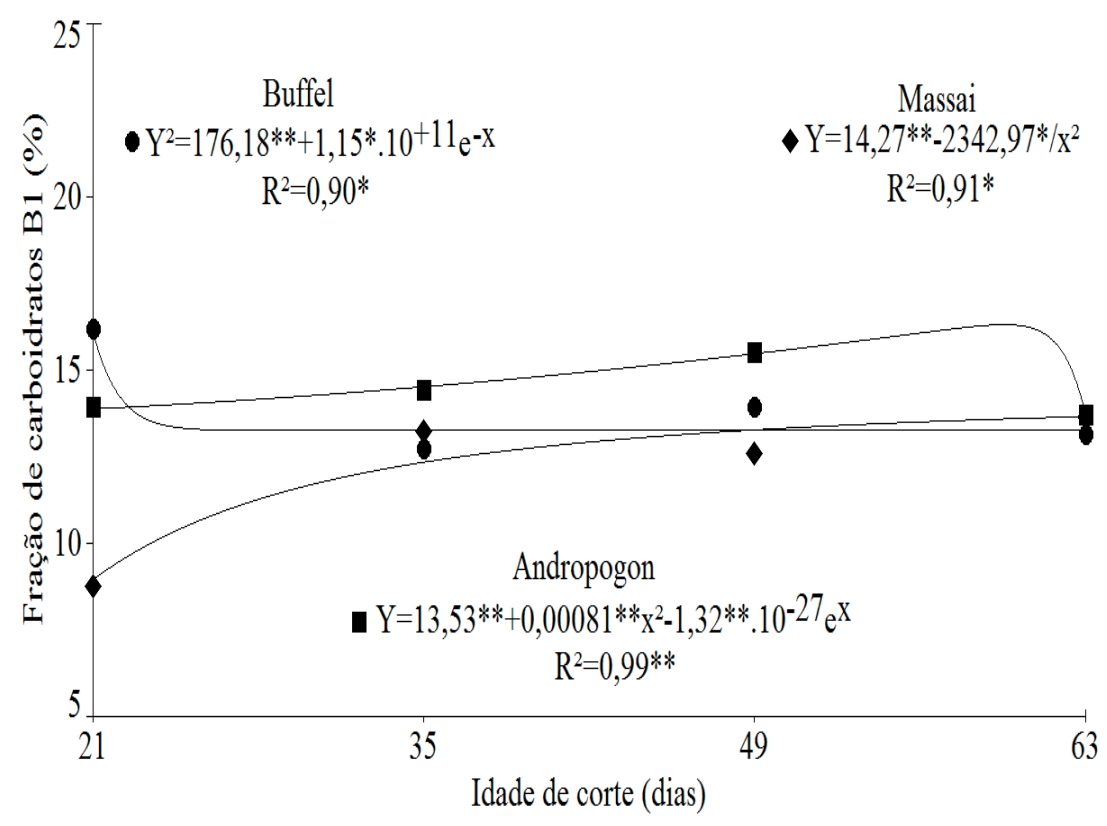

On the other hand, fraction B2 increased with the concentration of NDF over cell content increasing cutting age. Thickening of the secondary cell wall with maturation of plant tissues increases

(WILSON, 1989; VELÁSQUEZ et al., 2010).

This behavior was evident in the three species 
studied, as an increase was observed in NDF and ADF, concomitantly with forage maturation, whereby total carbohydrates and fraction B2 increased. The values were similar in hays of different ages, (Figure 8), making up the totality of carbohydrates. Bulk foods with higher NDF contents have a higher proportion of fraction B2, which, by supplying energy more slowly in the rumen, may affect the efficiency of microbial synthesis and animal performance. In addition, consumption may be limited by the high indigestible fraction (fraction C) of these forages (MALAFAIA et al., 1998; CABRAL et al., 2000; RIBEIRO et al., 2001). Thus, this forage should be supplemented with energy sources of fast rumen availability when there is no quantitative of qualitative protein limitation.

Figure 8. Cutting age effect on the content of carbohydrate fraction B2 in Andropogon, Buffel and Massai grass species.

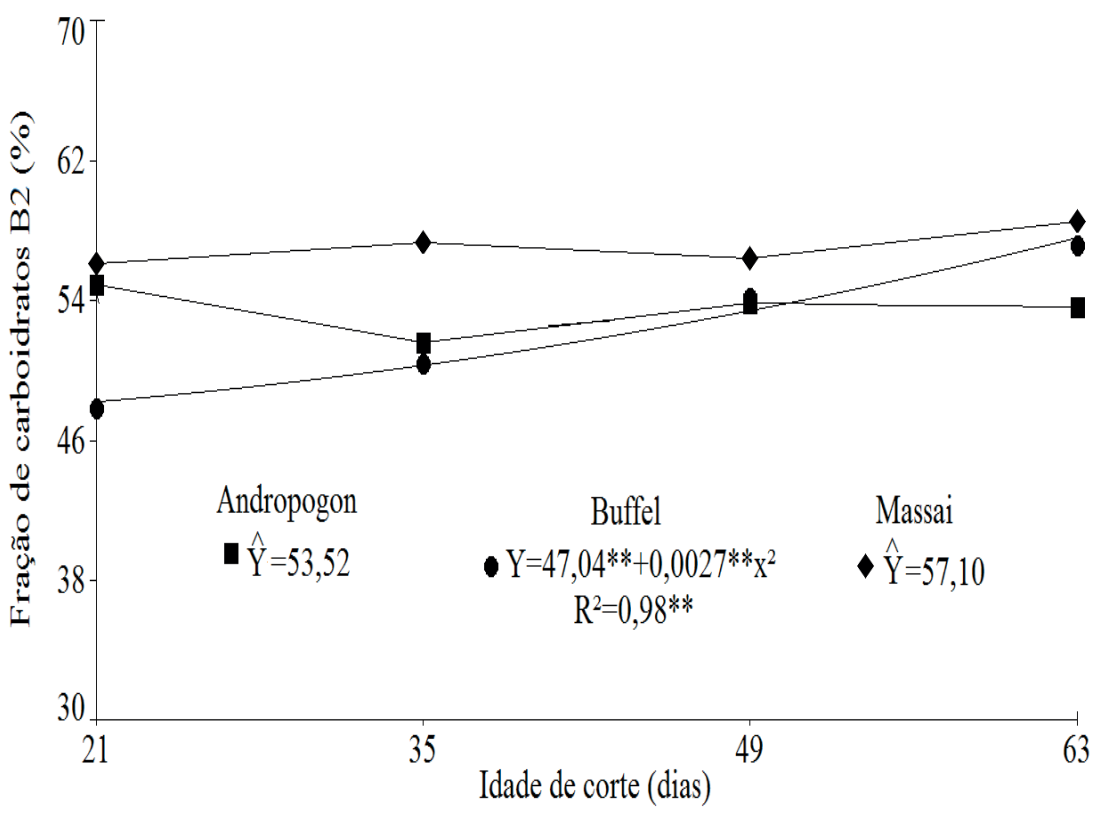

Fraction C, (Figure) showed an increasing linear behavior with cutting age, although in a grass dependent fashion. Thus, it varied between $7.07 \%$ and $15.08 \%$ of total carbohydrates percent in Andropogon grass and between $12.96 \%$ and $13.57 \%$, for Buffel grass, which was likely related to abundant flowering in this species during the experiment. As for fraction $\mathrm{C}$ values for Massai grass, these varied between $8.86 \%$ to $12.45 \%$, which were the lowest values for fraction $\mathrm{C}$, probably due to the abundance of leaves in this species during these experiments, whereby the fraction of hemicellulose and cell wall indigestible cellulose, would be expected to increase. According to Van Soest (1994), the indigestible fraction of total carbohydrates tends to increase with plant maturity (RIBEIRO et al., 2001). However, there is a tendency for the indigestible proportion of lignin to increase with hay age, which is an undesirable effect from the nutritional point of view.

Dry matter content (DM) showed increasing values with age for the three species analyzed, with no significant interaction between species and age $(\mathrm{p}<0.05)$. Conversely, the values for Mineral Matter $(\mathrm{MM})$ presented interaction $(\mathrm{p}<0.05)$ 
between species and age, showing a decrease in mineral residue with age in the three species. (Table 1) The Andropogon species presented lower MM values $(7.05 \%$ to $5.93 \%)$, in relation to the other two species, while values in Buffel and Massai grasses ranged from 12.04 to $8.57 \%$. Evaluating the growth and chemical composition of several grasses -Andropogon grass among them- at 21 and 63 days of age, Gonçalves and Costa (1987) found a decrease in MM levels from $6.14 \%$ to $5.22 \%$ for ages 21 and 63 days, respectively. Santos et al. (2005), found similar values for Buffel grass, which ranged from $11.44 \%$ to $9.37 \%$. According to Veiga and Camarão (1984), and Cavalcanti (2014), the leaves are generally the richer parts of the plant in mineral content. As the plant ages, there is a decrease in the proportion and quality of the leaves, which consequently results in a decrease in plant MM content.

Figure 9. Cutting age effect on the content of carbohydrate fraction C in Andropogon, Buffel and Massai grass species.

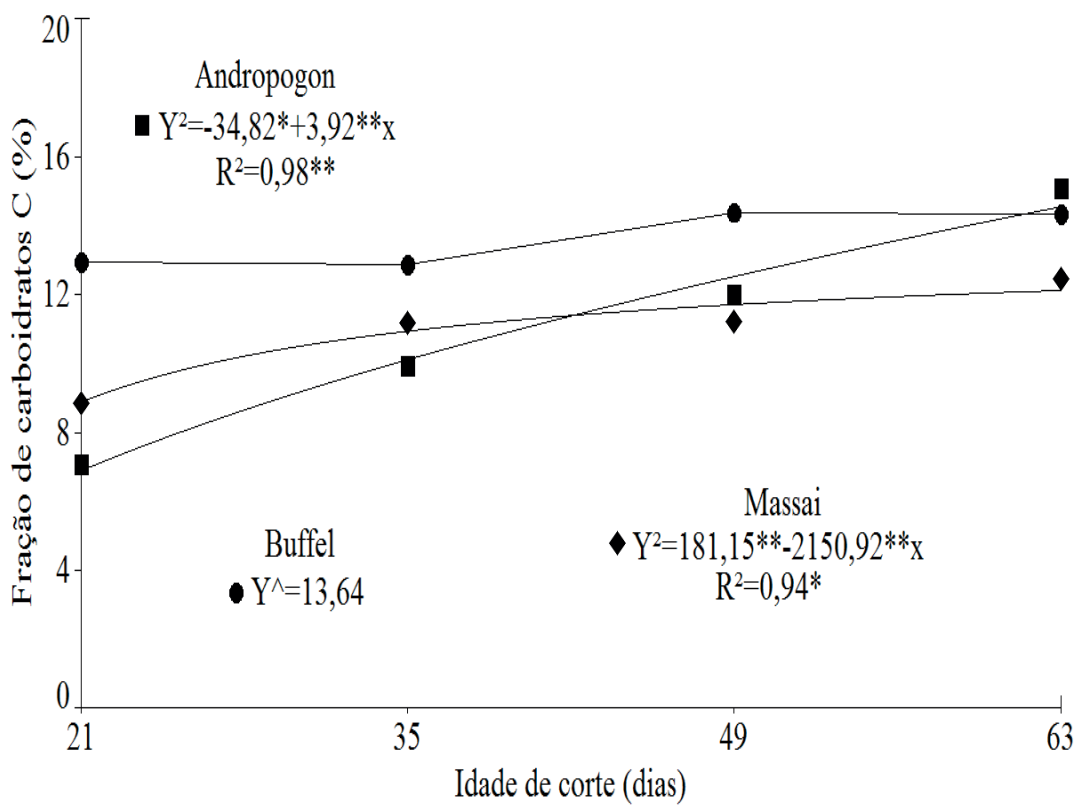

Crude protein $(\mathrm{CP})$ analysis showed a significant interaction between species and age $(\mathrm{p}<0.05)$, with decreasing $\mathrm{CP}$ content with increasing cutting age in the three species studied. (Table 1) According to Van Soest (1994), protein reduction is mainly due to reduction of the leaf to stem ratio, which occurs as fodder age increases. The longer it lives, the higher the nutritional value of the forage, because the leaves are the fraction of the forage plant with the highest digestibility, due to their richer content in crude protein and lower fiber content. This will determine an increase in consumption by the animals. Decrease in crude protein levels with age suggests that cutting season is important to ensure adequate amounts of crude protein in the grass, with 21 days being the recommended age for the most demanding animal categories.

The CP values found in this work at the cutting ages analyzed were as follows: for Andropogon grass, from $14.69 \%$ to $9.92 \%$; for Buffel from $12.21 \%$ to $6.2 \%$, while in the Massai grass values ranged between $11.11 \%$ and $7.17 \%$. Considering the importance of $\mathrm{CP}$ content on the physiological 
processes in ruminants, Gonçalves and Costa (1987) have proposed that CP levels lower than 6\% are limiting for the consumption of these species by animals; this may be due to low voluntary consumption and lower digestibility coefficients. Minson (1971) and Van Soest (1994), stated that this would be the estimated minimum level of $\mathrm{CP}$ for the food to have adequate ruminal fermentation. Therefore, according to our findings, at an advanced age, Buffel grass should be supplemented with other protein sources for animal feeding purposes.

Table 1. Chemical composition of grass species Andropogon, Buffel and Massai, at different cut-ages.

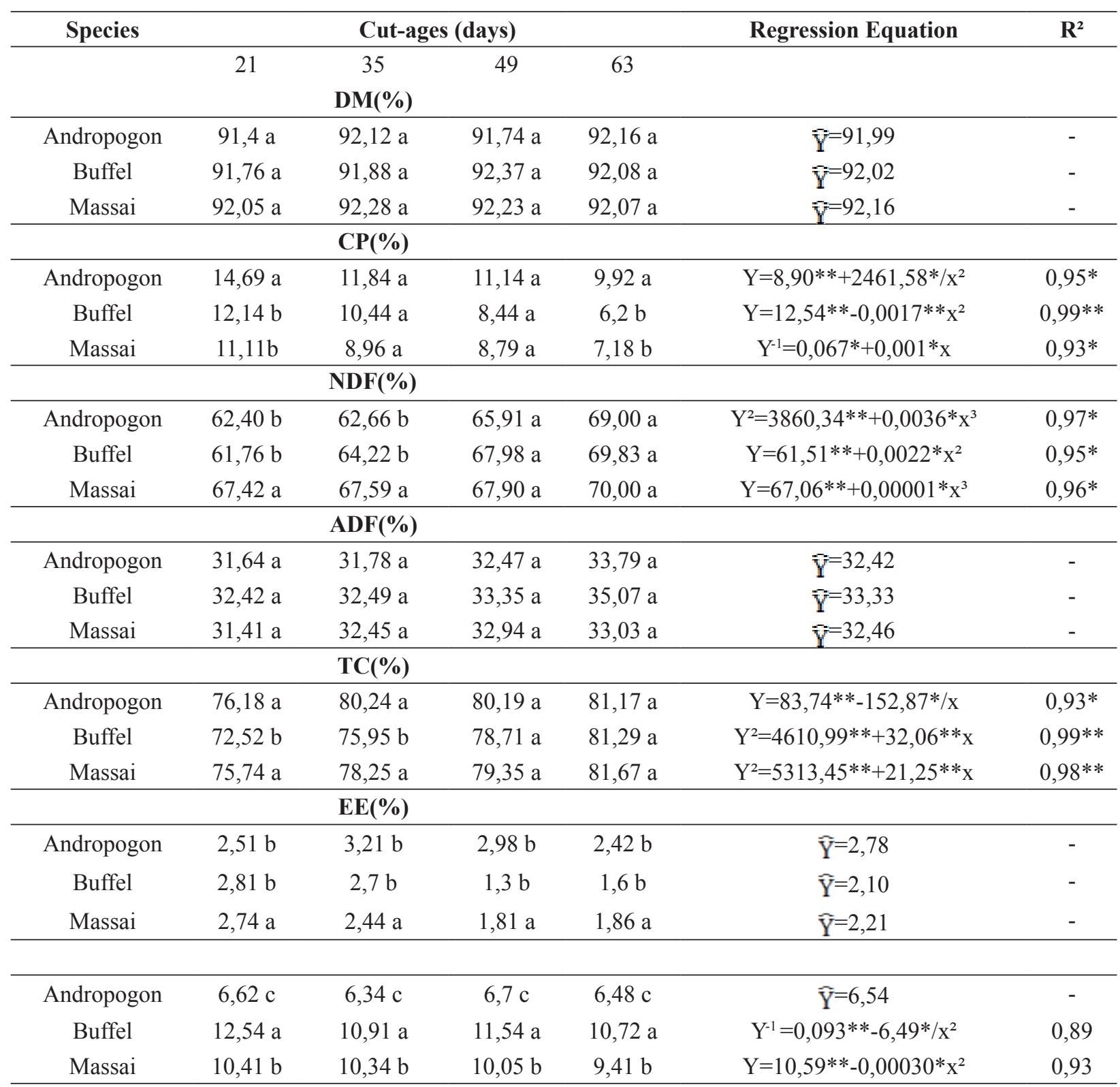

Means followed by different letter within columns differ from each other by Tukey's test at $5 \%$ probability $\mathrm{DM}=$ dry matter; $\mathrm{CP}=$ crude protein; $\mathrm{NDF}=$ neutral detergent insoluble fiber; $\mathrm{ADF}=$ acid detergent insoluble fiber; $\mathrm{TC}=$ total carbohydrates; $\mathrm{EE}=$ ethereal extract; $\mathrm{MM}=$ mineral matter. 
Analysis of Ethereal Extract (EE) showed no significant interaction between species and age ( $p$ $<0.05$ ), with decreasing amounts as cutting age increased in the three species in question. Values were found between: $3.21 \%$ and $1.3 \%$. According to Van Soest (1994), tropical grasses usually have low levels of EE, which are basically essential oils (pigments, waxes, glycolipids and membrane phospholipids) or substances soluble in non-polar solvents, with negligible nutritional value.

The analysis of fiber revealed that NDF did not show a significant interaction between species and age ( $\mathrm{p}<0.05$ ), while ADF did. Both, NDF and ADF increased with cutting age in the three species studied. The following NDF value ranges were found over the course of the sampling period: Andropogon (62.4\% to $69 \%)$; Buffel $(61.7 \%$ to $69.83 \%)$ and Massai (67.42\% to $70 \%$ ). The corresponding ADF values were as follows: Andropogon (31.64\% to $33.79 \%$ ); Buffel (32.41\% to 35.07$)$ and Massai $(31.41 \%$ to $33.03 \%$ ). Rodrigues et al. (2001), recorded value ranges from $61.32 \%$ to $66.24 \%$ and from $32.82 \%$ to $36.89 \%$ for NDF and ADF, respectively. The main changes that occur in the chemical composition of forage plants are those that accompany their maturation. As the plant ages, the proportion of potentially digestible components tends to decrease, while the proportion of fibers increases (SANTANA et al., 1989; RODRIGUES et al., 2001). As plants age, a reduction in leaf tissue percentage occurs and, consequently, an increase in stalk percentage contributes more to dry matter accumulation. As a result, the contribution of cell wall constituents increases, i.e., the proportion of the potentially digestible components tends to decrease, while the proportion of fibers increases. This requires more attention with respect to management in order to avoid a sharp decrease in the nutritional value of the forage. The average levels found in this study are within the average recorded for grass forages.

Total Carbohydrate (TC) values also showed a significant interaction $(p<0.05)$ between species and age, presenting increasing amounts with increasing cutting age in the three species studied. The levels of fibrous carbohydrates in grasses are higher in stems than in leaves. As plants mature, they experience an increase in fibrous carbohydrate content and a reduction in the non-fibrous carbohydrates, due to the increase in cellular wall constituents and the decrease in cellular content. These changes influence the digestibility of forage, which declines with increasing age (SILVA; SILVA, 2014).

\section{Conclusions}

Andropogon grass showed higher levels of crude protein in relation to the other species analyzed in the experiments reported herein. Massai grass showed higher fiber content and lower crude protein content. Andropogon and Massai grasses showed the highest fractions of intermediate degradation protein (B2), which may represent a protein contribution to ruminal degradation, as well as a better nutritional quality in these forage crops. Andropogon and Buffel grasses exhibited larger fractions of non-fibrous carbohydrates (A and B1), indicating greater aptitude for providing readily available energy. The indigestible fraction (C) of protein and carbohydrate contents increased with cutting age. This increase evidenced the effect that fraction $\mathrm{C}$ exerts on the nutritional value of the forages, consequently, reducing hay quality.

\section{References}

BALSALOBRE, M. A. A.; CORSI, M.; SANTOS, P. M.; VIEIRA, I.; CÁRDENAS, R. R. Composição química e fracionamento do nitrogênio e dos carboidratos do capim-tanzânia irrigado sob três níveis de resíduo póspastejo. Revista Brasileira de Zootecnia, Viçosa, MG, v. 32, n. 3, p. 519-528, 2003.

CABRAL, L. S.; VALADARES FILHO, S. C.; MALAFAIA, P. A. M.; LANA, R. P.; COELHO SILVA, J. F.; VIEIRA, R. A. M.; PEREIRA, E. S. Frações de carboidratos de volumosos tropicais e suas taxas de degradação estimadas através da técnica de produção de gases. Revista Brasileira de Zootecnia, Viçosa, MG, v. 29 n. 6, p. 2087-2098, 2000. 
CAVALCANTI, A. C. Valor nutricional do feno de Andropogon gayanus colhido em diferentes idades. 2014. Tese (Doutorado em Nutrição Animal) - Universidade Federal de Minas Gerais. Escola de Veterinária, Belo Horizonte.

GONÇALVES, C. A.; COSTA, N. de L. Curva de crescimento de capim elefante cv. Cameroon nos cerrados de Rondônia. Porto Velho: Embrapa Amapá, 1987. 7 p. (Folderes/Folhetos/Cartilhas - INFOTECA-E).

GONÇALVES, G. D. Avaliação nutricional de gramíneas do gênero Cynodon. 2001. Dissertação (Mestrado em zootecnia) - Universidade Estadual de Maringá, Maringá.

LICITRA, G.; HERNANDEZ, T. M.; VAN SOEST, P. J. Standardization of procedures for nitrogen fractionation of ruminant feeds. Animal Feed Science and Technology, Amsterdam, v. 57, n. 4, p. 347-358, 1996.

LOUSADA JÚNIOR, J. E.; COSTA, J. M. C.; NEIVA, J. M. N.; RODRIGUEZ, N. M. Caracterização físicoquímica de subprodutos obtidos do processamento de frutas tropicais visando seu aproveitamento na alimentação animal. Revista Ciência Agronômica, Fortaleza, v. 37, n. 1, p. 70-76, 2006.

MALAFAIA, P. A. M.; VALADARES FILHO, F. C.; VIEIRA, R. A. M.; COELHO SILVA, J. F.; PEREIRA, J. C. Determinação das frações que constituem os carboidratos totais e da cinética ruminal da fibra em detergente neutro de alguns alimentos para ruminantes. Revista Brasileira de Zootecnia, Viçosa, MG, v. 27, n. 4, p. 790-796, 1998.

MINSON, D. J. The digestibility and voluntary intake of six varieties of Panicum. Australian Journal of Experimental Agriculture, Melbourne, v. 11, n. 48, p. 18$25,1971$.

MOREIRA, J. A. de S. Características morfogênicas, estruturais e produtivas de acessos de capim-buffel. 2013. Dissertação (Mestrado em Zootecnia) - Universidade Federal de Sergipe, São Cristóvão.

NIMER, E. Climatologia do Brasil. Rio de Janeiro: IBGE, 1989. $421 \mathrm{p}$.

RIBEIRO, K. G.; PEREIRA, O. G.; VALADARES FILHO, S. C.; GARCIA, R.; CABRAL, L. S. Caracterização das frações que constituem as proteínas e os carboidratos, e respectivas taxas de digestão, do feno de capim-Tifton 85 de diferentes idades de rebrota. Revista Brasileira de Zootecnia, Viçosa, MG, v. 30, n. 2, p. 589-595, 2001.

RODRIGUES, L. R. A.; MONTEIRO, F. A.; RODRIGUES, T. J. D. Capim elefante. In: SIMPÓSIO SOBRE MANEJO DA PASTAGEM, 17., Piracicaba, 2001, Piracicaba. Anais... Piracicaba: FEALQ, 2001. p.
203-224.

RUSSELL, J. B.; CONNOR, J. D. O.; FOX, D. G.; VAN SOEST, P. J.; SNIFFEN, C. J. A net carbohydrate and protein system for evaluating cattle diets: I. Ruminal fermentation. Journal of Animal Science, Madison, v. 70, n. 11, p. 3551-3561, 1992.

SÁ, J. F.; PEDREIRA, M. S.; SILVA, F. F.; BOMONO, P.; FIGUEIREDO, M. P.; MENEZES, D. R.; ALMEIDA, T. B.Fracionamento de carboidratos e proteínas de gramíneas tropicais cortadas em três idades Carbohydrates and proteins fractions of tropical grasses cut at three ages. Arquivo Brasileiro de Medicina Veterinária e Zootecnia, Belo Horizonte, v. 62, n. 3, p. 667-676, 2010.

SANTANA, J. R. de; PEREIRA, J. M.; ARRUDA, N. G. de; MORENO R., M.A Avaliação de cultivares de capimelefante (Pennisetum purpureum Schum.) no Sul da Bahia. I. Agrossistema Cacaueiro.Revista da Sociedade Brasileira de Zootecnia, Viçosa, MG, v. 18, n. 3, p. 273283, 1989.

SANTOS, G. R. de A.; GUIM, A.; SANTOS, M. V. F.; FERREIRA, M. A.; LIRA, M. A.; DUBEUX JUNIOR, J. C. B.; JOSE SILVA, M. UFRPE. Caracterização do pasto de capim-buffel diferido e da dieta de bovinos, durante o período seco no sertão de Pernambuco. Revista Brasileira de Zootecnia, Viçosa, MG, v. 34, n. 2, p. 454463, 2005.

SILVA, D.; QUEIROZ, A. C. de. Análise de alimentos: métodos químicos e biológicos. Viçosa, MG: UFV, Impr. Univ., 2002. 166 p.

SILVA, S. P. da; SILVA, M. M. C. da. Fracionamento de carboidrato e proteína segundo o sistema CNCPS. Veterinária Notícias, Uberlândia, v. 19, n. 2, p. 95-108, 2014.

SNIFFEN, C. J.; O'CONNOR, J. D.; VAN SOEST, P. J.; FOX, D. G.; RUSSELL. J. B. A net carbohydrate and protein system for evaluating cattle diets: II. Carbohydrate and protein availability. Journal of Animal Science, Cornell University, Ithaca, NY, v. 70, n. 11, p. 3562-3577, 1992.

VAN SOEST, P. J. Nutritional ecology of the ruminant. New York: Cornell University Press, 1994. 463 p.

VEIGA, J. B. da; CAMARÃO, A. P. Produção forrageira $e$ valor nutritivo de capim-elefante (Pennisetum purpureum, schum) vars. Anão e Cameroon. Belém: EMBRAPA, 1984. v. 54, 137 p.

VELÁSQUEZ, P. A. T.; BERCHIELLI, T. T.; REIS, R. A.; RIVERA, A. R.; DIAN, P. H. M.; TEIXEIRA, I. A. M. A. Composição química, fracionamento de carboidratos e proteínas e digestibilidade in vitro de forrageiras tropicais em diferentes idades de corte. 
Revista Brasileira de Zootecnia, Viçosa, MG, v. 39, n. 6, p. 1206-1213, 2010.

WILSON, J. R.; ANDERSON, K. L.; HACKER, J. B. Dry matter digestibility in vitro of leaf and stem of buffel grass (Cenchrus ciliaris) and related species and its relation to plant morphology and anatomy. Australian
Journal of Agricultural Research, Clayton South, v. 40, n. 2, p. 281-291, 1989.

YEMM, E. W.; WILLIS, A. J. The estimation of carbohydrates in plant extracts by anthrone. Biochemical Journal, Londres, v. 57, n. 3, p. 508, 1954. 